Caligrama, Belo Horizonte, v. 22, n. 2, p. 135-155, 2017

\title{
O cuidado de si: uma análise acerca da defesa pela castidade masculina no cristianismo medieval
}

\section{Care of the self: an analysis about the defense of male chastity in medieval Christianity}

Bruna Plath Furtado

Universidade Estadual de Maringá, Maringá, Paraná / Brasil

brunaplath@hotmail.com

Roselene de Fátima Coito

Universidade Estadual de Maringá, Maringá, Paraná / Brasil

roselnfc@yahoo.com.br

Resumo: $\mathrm{O}$ presente trabalho tem por objetivo principal analisar como emerge na obra Virgeu de consolaçon uma cultura do cuidado de si cristão. Para tanto, tem-se como principais pressupostos teóricos a história do sujeito sob uma perspectiva do cuidado de si, elaborada por Foucault sobretudo no terceiro volume da História da sexualidade. O corpus selecionado para esta investigação compõe-se do capítulo 12 de Virgeu de consolaçon, obra portuguesa do século XIV que trata da castidade defendida pela doutrina católica e à qual se submetem os homens e as mulheres que devotam sua vida à causa religiosa. Procura-se identificar no corpus estudado - a partir do modelo ascético-cristão do cuidado de si historicamente contextualizado - formas de emergência de uma defesa pela abstinência sexual como uma prerrogativa da purificação do coração e da aproximação dos homens a Deus.

Palavras-chave: análise de discurso; cuidado de si; castidade; cristianismo medieval. 
Abstract: The objective of this paper is to analyze how the culture of Christian care of the self emerges in the book Virgeu de consolaçon. For this, this article has as main theoretical presuppositions the history of the subject, from a perspective of care of the self, elaborated by Foucault especially in the third volume of The History of Sexuality. The corpus used for this investigation is composed of the chapter 12 of Virgeu de consolaçon, Portuguese work from the $14^{\text {th }}$ Century that deals with the chastity defended by catholic doctrine to which men and women dispose of their life to the religious cause. This study seeks to identify, in the studied corpus, forms of emergence of a sexual abstinence defense as a prerogative to heart purification and to approach men to God, from the perspective of the ascetic-Christian model of care of the self, socially and historically contextualized.

Keywords: discourse analysis; care of the self; chastity; medieval Christianity.

Recebido em: 30 de setembro de 2017.

Aprovado em: 15 de dezembro de 2017.

\section{Introdução}

Este trabalho procura desenvolver uma análise baseada em um texto português do século XIV, sobre o qual ainda não foram desenvolvidos estudos pelo viés da análise de discurso, tendo como ponto de partida o conceito de cuidado de si desenvolvido pelo filósofo Michel Foucault (1985). Para tanto, selecionamos como corpus o capítulo 12 da obra denominada Virgeu de consolaçon, ${ }^{1}$ direcionada aos homens que dedicavam a vida ao cristianismo. O capítulo em questão aborda especificamente a castidade masculina, apresentando informações sobre sua importância e sobre como mantê-la.

Desse modo, temos por objetivo analisar como emerge, no capítulo 12 da obra Virgeu de consolaçon, uma cultura do cuidado de si cristão. Buscamos compreender o sujeito e seu corpo enquanto

\footnotetext{
${ }^{1}$ O Virgeu de consolaçon é um texto doutrinário cristão português do século XIV que apresenta questões relativas aos sete pecados e às virtudes humanas e faz parte dos Códices Alcobacenses.
} 
um cuidado de si que atende às prerrogativas do que se entende por castidade numa perspectiva cristã que chegou até nós nos dias de hoje. Para isso, apresentaremos uma contextualização acerca da história do sujeito pelo viés do cuidado de si, conforme elaborado por Foucault (1985) e descreveremos como se constrói no corpus selecionado uma argumentação em favor da castidade, em função da necessidade que o homem tem de cuidar de si mesmo.

Partimos de um levantamento teórico a respeito do conceito de cuidado de si nos estudos desenvolvidos por Foucault (1985, 1997, 2006) ao traçar a história do sujeito ocidental pelo viés da sexualidade. Em seguida, apresentamos as análises que desenvolvemos. Por último, tecemos nossas considerações finais.

\section{A cultura e o cuidado de si}

Foucault (2006, p. 301-323) define cuidado de si - ou epiméleia heautôे - como o fato de o sujeito ocupar-se consigo e de preocuparse consigo, e separa a história dessa prática em três momentos: o de surgimento da epiméleia heautoû no pensamento filosófico, que ocorre no período socrático-platônico; o momento em que se pode reconhecer a idade de ouro da cultura de si, situado nos dois primeiro séculos de nossa era; e, por último, o período entre os séculos IV e V, quando se passa da ascese filosófica pagã para o ascetismo cristão.

Tendo como ponto de partida a epiméleia heautô̂, Foucault (1997, p. 109) propõe uma pesquisa sobre a história e os modos instituídos do conhecimento de si, questionando-se, sobretudo, acerca do estabelecimento do sujeito como um objeto de conhecimento desejável e mesmo indispensável. Para responder a tais questionamentos, Foucault (1997, p. 109) utiliza como fio condutor os procedimentos que, conforme ele, existem em toda civilização e são prescritos aos indivíduos para fixarlhes a identidade, mantê-la ou transformá-la, visando determinados fins, a partir de relações de domínio de si sobre si, de conhecimento de si por si. A esses procedimentos o autor denomina "técnicas de si". A proposta de Foucault (1997, p. 109) ao conduzir seus estudos sob a perspectiva das "técnicas de si" é, partindo do imperativo de "conhecer-se a si mesmo", ampliá-lo para questões como "que fazer de si mesmo?", "que trabalho operar sobre si?", "como 'se governar"” quando se age sendo objeto dessas ações e o escopo onde elas incidem? 
No percurso para compreender esse conhecimento de si, e ao tratar do primeiro momento da epiméleia heautoû, Foucault (1997, p. 110) coloca o Alcebíades, de Platão, como ponto de partida da questão do "cuidado de si" e explica-nos que a história do "cuidado" e das "técnicas" de si seriam uma outra forma - não mais pelo viés da loucura - de fazer a história da subjetividade. Nessa nova forma, colocarse-ia em evidência o sujeito que vive, fala e trabalha, pondo em cena o empreendimento e as transformações das relações consigo mesmo, suas técnicas e seus efeitos de saber.

A respeito do segundo momento da epiméleia heautô, Foucault (1985, p. 43-73) procura expor-nos o fato de que nesse contexto da "cultura de si" iniciado na antiguidade, desenvolveram-se, nos dois primeiros séculos de nossa era, as reflexões sobre a moral dos prazeres. Para o autor, o que houve não foi um alargamento das proibições, mas uma mudança na forma como o indivíduo deve se constituir um sujeito moral.

Ao analisar obras dos séculos I e II de nossa era, Foucault (1985, p. 47) destaca a insistência em uma defesa da atenção que se deve ter consigo mesmo. $\mathrm{O}$ surgimento desse imperativo se sobressai às novas interdições e torna-se primordial a vigilância; a necessidade de se evitar, por meio de um regime austero, toda a inquietação e quaisquer distúrbios do corpo e da alma, de se respeitar a si mesmo e suportar a privação dos prazeres ou limitá-los ao casamento e à procriação. Nesse ponto, Foucault (1985, p. 47) nos esclarece que a ampliação da austeridade sexual em relação à moral não acontece de modo a estreitar o código que define os atos proibidos em relação ao sexo, mas com vistas a intensificar a relação do indivíduo consigo mesmo, por meio da qual "o sujeito se constitui enquanto sujeito de seus atos".

A respeito dessa nova moral que se evidencia no início da nossa era, Foucault (1985, p. 47) destaca que durante o período helenístico e romano houve o crescimento de um certo individualismo que contribuiu progressivamente para o surgimento de espaços com aspecto privado, de valores de conduta pessoal e para o interesse do indivíduo por si próprio. Corroborando Foucault (1985, p. 47), Veyne (2009, p. 36-46) explica-nos que, nesse período, uma nova moral se fortalece por meio de lendas médicas e restringe, mesmo para os rapazes, o sexo ao casamento. Conforme Veyne (2009, p. 36), não se trata de puritanismo, mas de higiene. 
Essa austeridade sexual desvelada por Foucault (1985, p. 43-73) - cujas práticas são também descritas por Veyne (2009, p. 36-46) - no pensamento filosófico e médico dos dois primeiros séculos de nossa era, está permeada por questões relativas à desconfiança diante dos prazeres e pela insistência sobre os efeitos deles tanto para o corpo quanto para a alma. Conforme Foucault (1985, p. 43-73), essa austeridade pode ser recuperada em textos de filósofos como Sêneca, sendo recorrente o empréstimo dessa moral entre os textos dos autores cristãos. Nesse período torna-se tema central nas representações narrativas a relação entre a moça e o rapaz que se inicia quando ambos são atingidos e tornam-se simetricamente apaixonados (FOUCAULT, 1985).

Caracterizada a segunda fase do cuidado de si pelo reforço aos temas da austeridade, pelas recomendações de abstenção sexual, pela valorização da preferência pela virgindade em detrimento do uso dos prazeres, pela prescrição de uma fidelidade rigorosa e pela desqualificação do amor pelos rapazes, para Foucault (1985, p. 43-73) o que encontramos nessa filosofia da antiguidade é o esboço de outra moral destinada a ser, nos séculos seguintes, mais coercitiva e a ter validade mais geral. É sobre essa outra moral que trataremos a seguir.

\subsection{O cuidado de si na era cristã}

Antecedido por essa moral dos dois primeiros séculos de nossa era, foi a partir do século III que, conforme Foucault (2006, p. 301-323), formou-se o modelo cristão do cuidado de si ou o modelo ascético-cristão, que se trata de um conhecimento de si que está ligado complexamente ao conhecimento da verdade. Esse conhecimento de si é uma exigência da necessidade de se purificar o coração para que se compreenda a Palavra, de modo que é só pelo conhecimento de si que se pode ser purificado. Para o autor, nesse momento, evidencia-se uma relação circular entre o conhecimento de si, o conhecimento da verdade e o cuidado de si, já que o conhecimento de si é necessário para a purificação do coração que só então poderá receber a Palavra, ao mesmo tempo em que a Palavra precisa ser recebida para que se possa purificar o coração e realizar o conhecimento de si.

A conclusão para a qual Foucault (2006, p. 310) nos encaminha é a de que para "promover nossa própria salvação, devemos acolher a verdade: a que nos é dada no Texto e a que se manifesta na Revelação". 
Entretanto, uma vez que os sujeitos estão inseridos há séculos numa cultura de si, o conhecimento dessa verdade não se torna possível se eles não se ocupam consigo mesmos por meio de um aspecto do conhecimento que purifique o coração. Como consequência, afirma Foucault (2006, p. 301-323), esse conhecimento purificador de si por si mesmo só é possível se já tivermos uma relação com a verdade presente no Texto e na Revelação. O filósofo salienta que é "esta circularidade que [...] constitui um dos pontos fundamentais das relações entre cuidado de si e conhecimento de si no cristianismo" (FOUCAULT, 2006, p. 311). Assim, evidenciada essa circularidade, podemos compreender que o conhecimento de si é fundamental para que se possa realizar um cuidado de si que permitirá a purificação e o conhecimento da verdade.

Foucault (2006, p. 301-323) explica-nos que é no cristianismo, por meio de técnicas que têm como função dissipar as ilusões interiores, permitir o reconhecimento das tentações que se formam no interior do coração e escapar das seduções que podem nos vitimar, que o conhecimento de si é praticado, de modo que o método para isso prevê decifrar os processos secretos que acontecem na alma e cuja origem, o objetivo e a forma é necessário que se conheça. Por isso a necessidade, como explica o autor, de uma exegese de si. Nesse sentido, as técnicas da confissão seriam o caminho através do qual, pela exegese de si, o sujeito se libertaria daquilo que vai contra a Verdade da Palavra, uma verdade que não é colocada como vontade de verdade, principalmente nesse período e em um contexto cristão, mas como a verdade (im)posta e inquestionável da Palavra ou do Texto-Palavra.

Por último, Foucault (2006, p. 311) evidencia que, no cristianismo, o conhecimento de si não tem tanto a função de voltar ao eu para reencontrar a verdade que lhe cabe e o ser que se é; ao contrário disso, retorna-se a si para fundamentalmente renunciar-se a si. É pelo viés do cuidado de si, assim histórica e contextualmente caracterizado, que pretendemos lançar o olhar no corpus selecionado ao longo da análise que empreenderemos a seguir.

\section{$3 \mathbf{O}$ cuidado de si e a castidade cristã em um texto medieval}

A análise do capítulo 12 do Virgeu de consolaçon, intitulado "Da fala e conversaçon que os homẽes nõ devẽ aver cõ as molheres", permite-nos evidenciar, a partir do subsídio teórico de Foucault (2006, p. 301-323), como, numa relação circular com a verdade e a purificação 
do coração, o cuidado de si apresenta-se como uma prática extremante importante especificamente para o homem medieval que deseja manter a castidade e que quer aproximar-se de Deus.

$\mathrm{O}$ texto analisado constitui-se verdade à medida que introduz citações de várias autoridades, ${ }^{2}$ que, como tais, têm sua fala legitimada para tratar das virtudes humanas. Assim, nomes como São Jerônimo, Sêneca, Santo Agostinho, São João, Orígenes, São Basílio, Crisóstomo e Platão são apresentados ao longo do texto, seguidos de citação que evidencia sempre os cuidados que o homem deve ter em relação aos perigos para sua castidade e seu corpo. Pela análise, foi possível constatar que esses perigos têm na mulher a sua fonte, uma vez que ela é caracterizada como origem do pecado e da perdição do corpo masculino. O corpus não apresenta indícios de possibilidade de a quebra da castidade masculina ter como origem outro homem, ou seja, a prática sexual entre dois homens não aparece como uma possibilidade para a corrupção do corpo, o que pode ser considerado uma demonstração da moral vigente, que havia de alguma forma suprimido (desde o segundo momento da história do cuidado de si) o amor pelos rapazes, e que se insere na sequência de um período em que se constituiu no discurso uma bipolarização da prática sexual entre homem e mulher, como pudemos constatar na exposição do pensamento de Foucault (1985, 1997, 2006). Essa ausência pode ainda ser resultado de uma interdição, sobre a qual trata Foucault (2014, p. 9), que excluiria dos textos desse período considerações a respeito de uma prática sexual entre os homens.

O capítulo analisado inicia-se com a afirmação de que a conversa das mulheres ${ }^{3}$ deve ser causa de horror a todo homem, especialmente

\footnotetext{
2 Por "citação de autoridades" compreendemos, a partir de Maingueneau (1997, p. 100), o enunciado - entendido, nesse caso, como fragmento de discurso - cuja autoria se reputa a uma autoridade, sendo, geralmente, um enunciado conhecido por uma coletividade em que há o apagamento do "locutor" (1) diante de um "Locutor" (L), definido como o responsável pelo enunciado (autor efetivo), com credibilidade e cujo enunciado garante a validade do discurso.

${ }^{3}$ Para o desenvolvimento desta análise foram utilizados três diferentes dicionários de português medieval e português arcaico (cf. CUNHA, 1997; FILHO, 2013; SILVA, 2009). Nas reflexões tecidas ao longo desta seção substituímos, sempre que possível, as palavras em português arcaico por equivalentes contemporâneas e mantivemos as citações dos trechos da obra (de I a XII) na escrita original arcaica. As palavras mantidas na grafia arcaica foram grafadas em itálico ao longo do texto.
} 
para os que fizeram voto de castidade e que querem chegar à altura do conhecimento de Deus, como podemos observar pelo excerto I, a seguir:

I. A conversaçõ ou affazimento das molheres deve ser avorrecente a todo homẽ, specialmente a aqueles que fezerõ voto de castidade e que querẽ chegar a alteza do conhocimento de Deos, ca nẽhũu nõ pode aprazer aas molheres, que nõ aplaza aos diaboos (VEIGA, 1958, p. 87).

O substantivo affazimento, bem como a caracterização da "conversa das mulheres", emerge também como motivo de horror aos homens e possui sentido recuperável na expressão "as relações sexuais torpes" (SILVA, 2009, p. 14), o que demonstra, logo no primeiro trecho do capítulo, que a prática do ascetismo deveria compor as técnicas do cuidado de si do homem medieval casto. Na sequência, introduz-se, então, a justificativa para o horror que essas práticas devem causar em todos os homens, segundo a qual não se pode agradar às mulheres sem agradar também aos diaboos. Conforme Filho (2013, p. 168), para o cristianismo medieval os diaboos são cada um dos anjos rebeldes e seguidores de Satanás.

Nesse primeiro parágrafo, apresentam-se ao leitor, incialmente, as consequências do prazer masculino obtido por meio da relação com as mulheres. Tal apresentação permite ao homem conhecer-se sob um novo aspecto e compreender seu desejo sob a ótica religiosa cristã. A partir de então, o leitor pode, pelo conhecimento adquirido, compreender a necessidade de fugir à sedução da "conversa das mulheres" e das mulheres, executando a fuga como técnica de si.

Observa-se, a exemplo do exposto em I, que o texto compõe-se, ao longo do capítulo, de informações que permitem ao homem conhecer-se na medida em que se lhe apresentam as consequências do contato com a mulher, e que, até então, poderiam ser desconhecidas por ele pela falta do conhecimento de si. Uma vez que os perigos lhes são revelados, é possível aos homens cuidarem de si.

A partir dessa exposição inicial, apresentada em I, são introduzidas no texto citações de autoridades, por meio das quais expõem-se as informações pertinentes à temática e fundamentais à noção do conhecimento de si para o homem que preza por sua castidade. A primeira dessas citações é atribuída a São Jerônimo, segundo o qual 
II. [...] nõ pode o homẽ cõ todo seu entendimento parar mentes em Deos, que muito usa a companhia das molheres [...]. E diz que aquel he sandeo mais que os sandeos que por Cajon e aazo das molheres que poer em si maa fama (VEIGA, 1958, p. 87).

Em II, a citação atribuída a São Jerônimo demonstra ao leitor como a companhia e a conversa das mulheres são prejudiciais ao homem ao não permitir que ele escute a Deus e ao lançar a desonra e má reputação sobre ele. Assim, o homem é apresentado a algumas das consequências que a companhia das mulheres lhe impõe. O que há, novamente, nesse trecho, é o conhecimento de si, ou melhor, a falta dele. Dito de outra forma, desconhecer-se enquanto sujeito de instinto, que não se controla diante da possível sedução da conversa da mulher, leva o homem à desonra, como podemos ver pela afirmação de que o homem tanto fica desonrado (em II, "poer em si maa fama") como não consegue escutar a Deus (em II, "nõ pode o homẽcõ todo seu entendimento parar mentes em Deos"). Interessante notar que não há uma represália ao instinto em si, mas um controle que o homem deve ter dos seus instintos quando próximo a uma mulher, já que agradá-la significa agradar aos diabos. A partir desse trecho as informações acerca do conhecimento que o homem deve ter de suas fraquezas para que possa cuidar-se serão sempre, ao longo do capítulo, apresentadas por meio de uma citação de autoridade.

Na sequência da fala atribuída a São Jerônimo, lemos uma citação cuja autoria é atribuída a Sêneca:

III. [...] ante el queria aver olhos de lobo cerval ou lepeosos ou nẽhũus por tal que nõ podesse ver molheres (VEIGA, 1958, p. 87).

É possível compreender pela afirmação atribuída ao filósofo uma preferência por se ter olhos de lobo feroz, doentes, ou mesmo pela ausência de olhos, desde que não se pudesse ver mulheres. Nesse ponto, observamos, conforme o exposto por Foucault (1985, p. 43-73), que a austeridade recuperável nos textos filosóficos é apropriada pelos autores cristãos ao tratarem da moral do cristianismo. Nesse caso, a recuperação da fala do filósofo é pertinente, pois vem ao encontro da moral cristã e constitui com ela uma verdade que é necessário conhecer para o desenvolvimento de um cuidado de si e, consequentemente, para a purificação da alma. Desse modo, não poder ver as mulheres, ou seja, 
proteger os olhos da visão delas é uma técnica do cuidado de si que permite purificar a alma ou, pelo menos, não contaminá-la ou, ainda, desonrá-la. Da mesma forma, apropriar-se de um enunciado proferido por um santo da Igreja cristã para legitimar a voz da autoridade do dizer, intensifica a ameaça da conversa das mulheres. Isso vai se confirmando ao longo do texto.

No trecho seguinte, temos uma fala atribuída a santo Agostinho:

IV. [...] os clérigos stremadamente devẽ a esquivar e fugir aa conversaçõ e conpanhia da molheres, porque, assi como das brasas saaẽ faiscas e do ferro ferrugẽ e das serpentes peçonha, bem assy da cõpanhia e da conversaçon das molheres sempre nace desejo de toda maa cobijça. E diz que muy gram prol he ao homẽ nõ tanger a molher ẽ esta presente vida (VEIGA, 1958, p. 87).

Na citação recuperada em IV, o santo aconselha aos clérigos que fujam da conversa e da companhia das mulheres, justificando-se por meio de uma comparação segundo a qual assim como das brasas saem faíscas, do ferro, ferrugem e das cobras, veneno, da companhia da mulher sempre nasce desejo ávido e intenso. Nesse trecho, há, pela primeira vez no capítulo, declaradamente, uma indicação efetiva de qual deve ser a atitude do homem em relação à mulher: explica-se ao leitor que ele deve fugir-lhe. Assim, para o mal intrínseco à mulher, a única solução é a fuga, como também se evidencia no excertos V e VI, adiante. A citação IV é finalizada com a afirmação de que é de grande nobreza ao homem não tocar a mulher nesta vida.

V. Se o homẽ mancebo conversar muito ou morar cõ molheres, nuca lhe falecerá scandalo do diaboo (VEIGA, 1958, p. 87).

VI. [...] o melhor e mais certo remédio que homẽ pode aver pera vencer o mundo e as molheres, assy he fugir-lhe, ca toda las outras infirmidades e temtações homẽ pode vencer per outras maneyras, assi como per jejũus ou por vigílias, per oraçõ, per disciplina, etc., mais esta nõ se pode vencer ẽ outra guisa senõ fugindo-lhe (VEIGA, 1958, p. 87).

Assim, para o homem cuja castidade é cara, o cuidado de si requer como técnica que ele se mantenha afastado das mulheres. Pode- 
se notar, também, que as mulheres são comparadas ao mundo, o qual, pela descrição do enunciado em VI, é cheio de tentações e enfermidades. Cabe ao homem vencê-las, tanto as mulheres como as outras tentações e enfermidades, sendo que essas duas últimas devem ser combatidas de modo diferente daquele que utiliza para vencer as mulheres (em VI, "las outras infirmidades e temtações homẽ pode vencer per outras maneyras"). Como se esclarece em VI, essas outras enfermidades e tentações o homem pode conter por meio de jejuns, vigílias e orações, mas a mulher - também descrita em VI como uma enfermidade e uma tentação - só pode ser vencida pela fuga (em VI, "mais esta nõ se pode vencer ẽ outra guisa senõ fugindo-lhe"). Destaca-se que o ato de vencer o mundo está condicionado ao sucesso obtido na luta contra as mulheres, uma vez que a técnica de fugir delas se apresenta como o melhor remédio que o homem possui para vencer o mundo (em VI, "o melhor e mais certo remédio que homẽ pode aver pera vencer o mundo e as molheres, assy he fugir-lhe"). Essa solução pela fuga, apresentada ao homem como a única possível, confirma-se em diversos outros trechos do capítulo. Entretanto, o que se destaca nos enunciados apresentados ao longo do texto é o fato de que, para justificar tal necessidade de fuga do homem em relação à mulher, atribui-se a ela toda a culpa pela corrupção do corpo e da castidade; atribuem-se-lhe também as mazelas da humanidade e a elas se atrelam os prazeres ao diabólico.

Conforme a citação atribuída a santo Agostinho em V, se o homem jovem conversar muito ou morar com mulheres, nunca morrerá nele o escândalo atribuído ao diabo. Assim, pelo enunciado em questão, compreende-se que se esses atos acarretam a permanência sobre o homem do escândalo atribuído ao diabo, é porque a causadora do escândalo é a mulher, como já fora dito e nesta passagem se reforça. Em outros trechos do texto, ${ }^{4} \mathrm{o}$ homem é aconselhado a não querer que os pés da mulher entrem em sua casa e a não desejar conversar com as virgens servas de Jesus Cristo, ainda que elas vivam em santidade. Verifica-se, novamente, a desconfiança com relação à mulher e, ao mesmo tempo, a incapacidade de o homem controlar seus instintos diante dela.

\footnotetext{
${ }^{4}$ Muitos enunciados que mencionamos e descrevemos ao longo da análise não foram expostos integralmente neste trabalho, devido à necessidade de concisão que um artigo exige. Por isso, indica-se, se possível, a leitura integral do capítulo sobre o qual esta análise se debruça.
} 
A partir do conhecimento de si que os enunciados demonstram, a técnica de si que permite ao homem medieval casto manter sua virtude está em se afastar das mulheres. Ao executar tal técnica, ele cuida de si e, como exposto em II, pode, então, escutar Deus e ter acesso à Palavra e à Revelação, purificando seu coração e alcançando a verdade e, novamente, praticando o cuidado de si. Eis aí a circularidade evidenciada por Foucault (2006), que podemos verificar em:

Pode-se dizer, creio, que neste modelo [cristão] o conhecimento de si está ligado, de modo complexo, ao conhecimento da verdade tal como é dada pelo Texto e pela Revelação; que este conhecimento de si é implicado, exigido pela necessidade de que o coração seja purificado para compreender a Palavra; que só pelo conhecimento de si ele pode ser purificado; que a Palavra precisa ser recebida a fim de que se possa empreender a purificação do coração e realizar o conhecimento de si. Portanto, relação circular entre: conhecimento de si, conhecimento da verdade e cuidado de si. Se quisermos promover nossa própria salvação, devemos acolher a verdade: a que nos é dada no Texto e a que se manifesta na Revelação. Mas não podemos conhecer esta verdade se não nos ocuparmos com nós mesmos na forma do conhecimento purificador do coração. Em troca, este conhecimento purificador de si por si mesmo só é possível sob a condição de que já tenhamos uma relação fundamental com a verdade, a do Texto e da Revelação. É esta circularidade que, a meu ver, constitui um dos pontos fundamentais das relações entre o cuidado de si e o conhecimento de si no cristianismo (FOUCAULT, 2006, p. 310-311).

Corroborando a hipótese que vem sendo aqui apresentada, enunciam-se em VII inúmeros exemplos de homens que perderam suas virtudes devido a uma mulher:

VII. Nõ queyras star nẽ ficar cõ a molher soo em hũa casa, nẽ te esfeuzes em tua castidade, nẽ em tua fortaleza nẽ ẽ tua sanctidade nẽen tua sabedoria, ca nõ es tu mais forte que Sanson nẽ mais santo que David nẽ mais sabedor que Salomõ. E todos estes cayron em pecados e deles em perigoos dos corpos, pelo aazo e conversaçon das molheres, ca o oolhar do rosto que muy ameude vees te trage a muy grande perigoo (VEIGA, 1958, p. 88). 
Por isso, em VII, o homem é aconselhado a não confiar na própria força, na própria santidade nem na própria castidade e, como argumento em favor desse aconselhamento, citam-se os exemplos de Sansão, David e Salomão, que pecaram e colocaram seus corpos em perigo devido à conversa das mulheres. Apresentam-se exemplos de homens que se deixaram corromper por não praticarem o cuidado de si necessário para que seus corpos não fossem corrompidos e ameaçados. Tais homens pecaram e, de um modo ou de outro, perderam suas vidas por causa das mulheres nas quais confiaram e com as quais permaneceram demasiadamente. Se, por um lado, à mulher é atribuído esse papel diabólico da sedução que corrompe corpos e cega mentes, impedindo a purificação e a revelação, por outro, ao homem é dado um papel de fraqueza moral diante de tal perigo. Nesse sentido, o aconselhamento se mostra paradoxal: a mulher é diabólica e o homem é fraco. É pelos exemplos de perdição trágica sofrida por aqueles que permaneceram sob o encanto feminino que o cuidado de si demonstra-se imperativo, uma vez que as consequências do descuidar-se são reais. ${ }^{5}$

\footnotetext{
${ }^{5}$ Sobre os exemplos em questão temos, primeiramente, a história de Sansão, que é narrada, na Bíblia, no livro de Juizes, capítulo 13. Conforme a narrativa bíblica (BÍBLIA, 1997a, p. 294), Sansão, que era um servo de Deus, conta a Dalila - que fora instruída a seduzilo e a descobrir a origem de sua força - que a força que o tornava invencível residia nas sete tranças de seu cabelo, que nunca fora cortado. Num golpe de traição, Dalila corta os cabelos de Sansão enquanto ele dorme, e o entrega aos filisteus. Prisioneiro dos filisteus, Sansão, por interseção divina, consegue forças para derrubar a coluna central da casa em que estava, morrendo esmagado, mas levando consigo todos os filisteus, que festejavam sua captura. No segundo exemplo, temos a história de adultério do rei Davi, que é narrada no segundo Livro de Samuel (BÍBLIA, 1997b, p. 346-348). Segundo a narrativa, o rei dormiu com Betsabé, que era esposa de seu general, Urias. A partir do adultério, Betsabé engravida e o rei Davi envia Urias para a frente de batalha, na intenção de que ele morresse, fato que se efetiva e que permite ao rei tornar Betsabé sua mulher. Entretanto, como consequência, Davi desagrada ao Senhor, que o pune tirando a vida de seu primeiro filho com a esposa. Betsabé engravida novamente de Davi e a criança, amada pelo Senhor, se torna o futuro rei de Israel, Salomão. Por último, temos a perdição de Salomão, filho de Davi, que também acontece por conta das mulheres que ele amou. Apesar de ter sido instruído por Deus a não ter relações com mulheres estrangeiras, pois elas o seduziriam o coração e o levariam para os seus deuses, Salomão teve 700 esposas e 300 concubinas, que perverteram-lhe o coração para seguir outros deuses. Diante disso, o Senhor promete retirar o reino da sucessão de Salomão, fazendo, após sua morte, não do filho dele, mas de um de seus servos, um rei (BÍBLIA, 1997c, p. 380).
} 
Se até aqui, no corpus, a companhia, a fala da mulher e o ato de tocá-la representava ameaças ao corpo e à castidade masculina, a partir deste ponto a contemplação, o muito olhar para o rosto da mulher é também causa de muitos perigos. Ao homem não restam alternativas; dois caminhos e suas respectivas consequências se revelam: a fuga da mulher ou o encontro com ela, a virtude ou a desonra, a salvação do corpo ou sua corrupção, Deus ou os diabos. A bipolaridade bem vs. mal firmase, confirma-se e se instaura como elemento retórico de convencimento para o homem casto. Nessa visão dicotômica do homem sobre o mundo e sobre a mulher, elimina-se a possibilidade de relativização dos atos, fato que marca esse posicionamento cristão avesso ao que é tomado como profano. É a radicalização dos polos que purifica ou castiga.

No excerto a seguir, ensina-se ao homem religioso que o amor das mulheres não pode ser saciado, pois mesmo depois de morto, ele se incendeia novamente e, após a grande satisfação, míngua e torna-se pobre, de modo que o coração do homem fica tão pequeno e fraco que ele não consegue pensar em outras coisas senão nesse mal que o faz sofrer.

VIII. O amor das molheres nuca pode ser farto, o qual depois que he morto, depois torna a ser encendido, e depois da grande avondança he fecto mjnguado e mesquinho e o coraçõ do homẽ faz tan pequeno e tã fraco, que non leixa pensar em outra cousa, senõ em aquel mal que sofre (VEIGA, 1958, p. 88).

Assim, conforme VIII, a aversão ao prazer que causa a grande satisfação é plenamente justificável, uma vez que esse prazer é efêmero e tem consequências muito negativas para o homem, que enfraquece e tem sua mente tomada pelo mal que o atingiu; o prazer passa da satisfação do corpo ao sofrimento que invade a mente e fragiliza o coração. Estabelecese, portanto, como já evidenciou Foucault (1985, p. 43-73) acerca do cuidado de si cristão, uma relação em que o prazer é atrelado ao mal, não apenas ao mal diabólico, como encontramos em excertos anteriores, mas também ao mal que perturba a mente e enfraquece o coração. Se a mente não se ocupa de outra coisa que não o mal que se instalou, como resultado de um descuido de si, o coração se afasta da purificação necessária ao cristão. Então, o prazer plenamente satisfeito torna-se um vício do qual o homem cristão não pode se libertar, instituindo o mal que a mulher provoca e a fraqueza moral do homem. 
No trecho destacado em IX, a corrupção do homem pela mulher é apresentada, explicitamente, pela primeira vez no corpus como tendo como resultado final o Inferno, que é sua consequência máxima. Afirmase que a descendência, a morada ou a companhia das mulheres é porta do Inferno, ferida de escorpião e muito prejudicial ao homem.

IX. Ca o linhagẽ ou morada ou aver companhia cõ ellas nõ he se nõ porta do inferno e ferida de scorpiõ, e cousa muy enpeencivil (VEIGA, 1958, p. 88).

Em última instância, o homem, pela ausência do cuidado de si quando se permite estar na presença da mulher, desvirtuando-se -abre para si as portas do Inferno.

O desejo é apresentado, em diversas passagens do corpus, metaforicamente como fogo, como aquilo que incendeia, e a própria palavra fogo aparece em enunciados que explicam que assim como o fogo queima o que está próximo dele, tocar a pele da mulher representa um perigo iminente àquele que a toca, pois a mulher fere com fogo mortal e queima aquele que mais próximo dela estiver, queimando a raiz de todo bom propósito e boa promessa.

O fogo é, portanto, a causa (desejo) com consequências (devastação); é o desejo que nasce da presença da mulher e que culmina no prazer, mas que também consome as virtudes, causa feridas e corrompe o corpo. O fogo é sedutor, mas devasta aquele que dele se aproxima. Nessa relação metafórica entre fogo e desejo, a conclusão para ambos é a mesma. A única forma de não se queimar, de não ser consumido pelo desejo é afastar-se da chama de origem.

Pelo conhecimento de si o homem pode compreender que, assim como a origem do incêndio que a tudo consome é chama inicial, a origem da corrupção do corpo, da perturbação da mente e do coração, bem como da condenação ao Inferno é a mulher. Como o fogo há de queimar aquele que muito dele se aproximar, a conclusão acerca do contato com uma mulher é, irremediavelmente, a corrupção. Assim a estratégia argumentativa em favor da castidade reside em dissipar a ilusão de que haveria alguma conversa entre homem e mulher que não seria para ele fonte de tentação, para, em seguida, apresentar a adequada técnica de si, que é a separação do homem da mulher. Acerca disso, verificamos com Foucault (2006, p. 311), conforme recuperado na seção 2.1, que é por meio das técnicas de si no cristianismo - das quais faz parte (pela 
análise apresenta até aqui) a defesa do afastamento do homem em relação às mulheres - que se torna possível ao homem o dissipação das ilusões interiores, o reconhecimento das tentações e, por fim, é possível a ele escapar das seduções.

Nessa construção de argumentos, que enfatiza o perigo da mulher, de seu discurso e a fraqueza moral do homem, Deus se torna impotente diante desse cenário, evidenciando, a partir da coerência as contradições como um reflexo da superfície (FOUCAULT, 2008, 169-170). ${ }^{6}$

$\mathrm{Na}$ sequência, em $\mathrm{X}$, a fala do bispo Johã é introduzida para alertar o homem do fato de que a mulher é malícia antiga, pois ela foi responsável por retirar Adão dos prazeres do Paraíso. Ressalta-se que Eva colocou toda a descendência humana no Inferno, tirou a vida do mundo, trouxe a morte aos homens, encontrou o trabalho, a dor e matou são João Batista, sendo, portanto, a mulher responsável por transformar os homens espirituais em terrenos.

X. A molher he malicia antiga a qual tirou Adam dos plazeres do parayso, e os homẽes spirituaaes faz-os terreaaes, por esta foy todo o linhagẽ humanal método no jnferno. Esta tolheo a vida ao mundo, esta he mal tã grande que trage os homẽes aa morte, esta achou primeyramente trabalho e door, esta matou san Johã Babtista (VEIGA, 1958, p. 88-89).

Observa-se, nesse ponto, como o mal atrelado ao prazer, na austeridade cristã, tem origem, pela mitologia católica da criação da humanidade, em Eva, que corrompe Adão e o influencia a comer do fruto proibido e, dessa forma, desobedecer às ordens divinas. Eva apresenta 0 pecado a Adão, planta nele o desejo e o torna mundano. Desse modo, a malícia feminina é intrínseca à sua origem e, uma vez que Eva corrompeu Adão, todas as descendentes dela serão também corruptoras de virtudes. Por esse motivo, todas as características femininas corrompem o homem e são, no texto analisado, genéricas e aplicáveis a qualquer que seja a

\footnotetext{
${ }^{6}$ A respeito da contradição, Foucault (2008, p. 170) esclarece-nos que ela "é a ilusão de uma unidade que se oculta ou que é ocultada: só tem lugar na defasagem existente entre a consciência e o inconsciente, o pensamento e o texto, a idealidade e o corpo contingente da expressão". Para o autor, "[t]al contradição, longe de ser aparência ou acidente do discurso, longe de ser aquilo de que é preciso libertá-lo [...] sua verdade aberta, constitui a própria lei de sua existência: é a partir dela que ele emerge" (FOUCAULT, 2008, p. 170).
} 
mulher (mesmo à serva de Jesus, mesmo à irmã de sangue). O mal que se enfatiza estar presente no prazer, durante o período cristão do cuidado de si, é o da essência feminina. Em citação atribuída a Orígines, a mulher também é a cabeça do pecado, animal ruim, serpente venenosa e serva má do mundo.

$\mathrm{Na}$ alegoria da mulher como animal peçonhento, rastejante, conserva-se o discurso da sua inferioridade diante do homem, que, mesmo moralmente fraco, é-lhe superior. Contudo, a insistência, tal qual a da serpente bíblica, faz o homem cristão sucumbir. Mais uma vez, conhecer-se é fundamental para o cuidado de si. Em ponto algum, a fraqueza moral do homem cristão é questionada, já que lhe é permitido ter fraquezas e vencê-las, ao passo que a mulher é, em sua imutável essência moral, fraca. Portanto, o discurso para alertá-la de sua fraqueza não teria sentido, contrariamente ao que acontece para o homem cristão. Dá-se como posto que a mulher não precisa conhecer-se, já que sua natureza é esta do pecado e da corrupção moral, e cabe ao homem cristão cuidarse de si para cuidar dos outros, inclusive da sua fé e da fé alheia, como técnica de purificação, da verdade e da revelação.

Nos últimos trechos do capítulo analisado, excertos XI e XII, os enunciados são atribuídos a são Basílio, que aconselha ao homem separar-se do amor das mulheres, não abandonar o amor de Deus e não querer ir à casa das virgens religiosas nem com elas muito falar. De onde podemos compreender que o caminho que leva ao amor de Deus é completamente oposto ao que leva ao amor das mulheres. Assim, não há possibilidade de o homem encontrar o amor das mulheres e também o divino. Não há aproximação de Deus para o homem que se aproxima das mulheres; ao contrário, há distanciamento e consequências funestas. Em XII, isso ascende irreversivelmente ao status de verdade, uma vez que o santo afirma não mentir, por falar em nome do próprio Jesus Cristo.

XI. Parte o teu amor das molheres e nõ te quites do amor de Deos, nom qu[e]yras hir a casa das virgẽes nẽ das religiosas, nẽ queyras ameude cõ ellas falar nẽ usar ne andar, por que pelos muitos e longos sermões delas son as almas ençujentadas (VEIGA, 1958, p. 89).

XII. E diz mais este sancto: Creede a mjn, porque esto que digo digo-o e falo-o em persoa de Cristo e em esto nõ menço (VEIGA, 1958, p. 89). 
Ao se afirmar falar em nome do próprio Jesus Cristo, a caracterização do desejo do homem pela mulher como maléfico, da presença da mulher e da conversa com ela como origem da tentação, dos prazeres como uma forma de agradar aos diabos, da mulher como fonte do pecado, como porta do Inferno, entre outras que remetem à austeridade cristã, ascendem a um patamar irreversível de verdade. Ao homem medieval que deseja alcançar ou manter a virtude da castidade para chegar a Deus, apresenta-se a verdade incontestável que permitirá a ele dissipar as ilusões interiores e reconhecer as tentações para seu coração e sua alma (conhecimento de si), e evidenciam-se para ele as técnicas de si necessárias ao cuidado de si que o permitirá, por meio da verdade, purificar o coração. Conforme apresentado na seção 2.1, Foucault (2006, p. 311) esclarece que o método para a prática dessas técnicas de si consiste em decifrar "os processos e movimentos secretos que se desenrolam na alma, dos quais é preciso apreender a origem, a meta, a forma", sendo necessária, portanto, "uma exegese de si". Nesse sentido, o corpus analisado e os enunciados que ele compreende funcionam como uma superfície da qual emergem informações e conselhos sobre como esse homem medieval casto se constitui, no que se refere ao seu contato com a mulher (suas fraquezas e os riscos que essa mulher lhe representa), servindo de instrumento dessa exegese e permitindo a esse homem o cuidado de si.

\section{Considerações finais}

Com nossa análise, pudemos observar que o capítulo 12 do Virgeu de consolaçon, lido a partir do conceito foucaultiano de cuidado de si, atua como um instrumento para que o homem casto conheça a si mesmo, o que permite a ele cuidar de si e, na relação circular evidenciada por Foucault (1985, p. 43-73), purificar-se e ter acesso à verdade. Somente por meio do conhecimento de si e do cuidar de si para poder cuidar dos outros, é que esse homem medieval cristão ascende à pureza e à verdade.

Contudo, observamos que há uma generalização das consequências dos prazeres, com a mulher vista como algo que afeta a todos os homens, apesar de o texto ter como foco aqueles homens que fizeram voto de castidade. Essa generalização se comprova no primeiro trecho do capítulo, exposto em I, onde se evidencia que a fala e as relações sexuais torpes com as mulheres devem ser causa de desonra a todo homem, 
ainda que especialmente àqueles que fizeram voto de castidade. Outro aspecto notado é o fato de que toda a argumentação apresentada se encaminha para uma única conclusão: ao homem que deseja manter ou alcançar a castidade, a única alternativa reside no isolamento completo dele em relação às mulheres. Por fim, não se considera a possibilidade da quebra da castidade por meio de uma relação entre dois homens, cuja ausência suscita questionamentos que outras investigações - nas quais se ampliasse, por exemplo, o corpus - poderiam responder.

Conforme os objetivos iniciais que havíamos traçado, contextualizamos, na seção 2, a história do sujeito pelo viés do cuidado de si. Procuramos descrever, por meio das análises apresentadas, como se constrói, no corpus selecionado, uma argumentação em favor da castidade, em razão de uma necessidade que o homem tem de cuidar de si mesmo, e buscamos, também, na seção 3, analisar como emerge, no capítulo 12 da obra Virgeu de consolaçon, uma cultura do cuidado de si cristão. Em relação a esses aspectos, a análise permitiu compreender que a defesa da castidade masculina reside em classificar qualquer prática entre homens e mulheres (o olhar, a conversa, a convivência, o morar junto, o tocar, entre outras) como perigosa para a virtude masculina. A mulher caracteriza-se nos enunciados estudados como fonte eminente de corrupção do corpo do homem e, consequentemente, afasta-o de Deus, colocando em risco sua salvação. Por esse motivo, torna-se imperativa a esse homem a prática do cuidado de si que consiste em fugir da presença de mulheres, uma vez que para essa forma de corrupção a única certeza de manter-se incorruptível é fugir à tentação que a mulher representa, quem quer que ela seja, incluindo-se as religiosas e a irmã de sangue. Nossa análise pôde constatar, também, como a cultura do cuidado de si cristão no corpus em questão caracteriza-se por um regime mais austero do modelo que Foucault (2006, p. 310) denomina ascético-monástico.

Também observamos, na evidência do dizer, os mecanismos de controle internos (em relação à escolha dos itens lexicais) e externos (por se apropriar de discursos proferidos por santos) para a constituição dos enunciados, autorizando-se este discurso como aquele que leva e eleva a verdade cristã sobre a castidade masculina, para que este homem medieval cristão atinja a pureza e com ela a revelação. Somente nessa castidade, que deve ser conhecida pelo si, é que o cuidado de si para cuidar do outro se torna possível, e isso só acontecerá mediante à demonização da mulher, seja enquanto uma figura alegórica ou não. 
Inúmeros outros aspectos não discutidos neste trabalho poderiam ser abordados, na análise do corpus que selecionamos, em relação à proposta de Foucault (1985, p. 43-73) para a constituição da história do sujeito pelo viés do cuidado de si. Por isso, esclarecemos que este trabalho não esgotou as análises possíveis. Reconhecemos, assim, a necessidade de outras investigações que abordem o cuidado de si no período cristão medieval, considerando, para tanto, o mesmo corpus e/ou outros corpora.

\section{Referências}

BÍBLIA. A. T. Juízes. Tradução dos originais mediante a versão dos Monges de Maredsous (Bélgica) pelo Centro Bíblico Católico. 107. ed. São Paulo: Ave Maria, 1997a. p. 276-301.

BÍBLIA. A. T. Livro de Samuel: segundo livro. Tradução dos originais mediante a versão dos Monges de Maredsous (Bélgica) pelo Centro Bíblico Católico. 107. ed. São Paulo: Ave Maria, 1997b. p. 336-365.

BÍBLIA. A. T. Livro dos reis: primeiro livro. Tradução dos originais mediante a versão dos Monges de Maredsous (Bélgica) pelo Centro Bíblico Católico. 107. ed. São Paulo: Ave Maria, 1997c. p. 365-397.

CUNHA, A. G. Dicionário Etimológico Nova Fronteira da Língua Portuguesa. 2. ed. Rio de Janeiro: Nova Fronteira, 1997.

FILHO, A. V. L. M. Dicionário etimológico do português arcaico. Salvador: EDUFBA, 2013.

FOUCAULT, M. A arqueologia do saber. Tradução de Luiz Felipe Baeta Neves. 7. ed. Rio de Janeiro: Forense Universitária, 2008.

FOUCAULT, M. A hermenêutica do sujeito. Tradução de Márcio Alves da Fonseca; Salma Tannus Muchail. 2. ed. São Paulo: Martins Fontes, 2006.

FOUCAULT, M. A ordem do discurso: aula inaugural no Collège de France, pronunciada em 2 de dezembro de 1970. Tradução de Laura Fraga de Almeida Sampaio. 24. ed. São Paulo: Edições Loyola, 2014.

FOUCAULT, M. História da sexualidade. Tradução de Maria Thereza da Costa Albuquerque. Rio de Janeiro: Edições Graal, 1985. v. 3: o cuidado de si.

FOUCAULT, M. Resumo dos cursos do Collège de France (1970-1982). Tradução de Andréa Daher. Rio de Janeiro: Jorge Zahar, 1997. 
MAINGUENEAU, D. Novas tendências em análise do discurso. 3. ed. Campinas: Pontes, Editora da UNICAMP, 1997.

SILVA, J. C. da. Dicionário da língua portuguesa medieval. 2. ed. rev. ampl. Londrina: Eduel, 2009.

VEIGA, A. de B. Virgeu de Consolaçon: edição crítica de um texto arcaico inédito. Porto Alegre: Livraria do Globo, 1958.

VEYNE, P. (Org.). História da vida privada. Tradução de Hildegard Feist. São Paulo: Companhia das Letras, 2009. v. 1: Do Império Romano ao ano mil. 